\title{
IMPLEMENTASI STRATEGIS MANAJEMEN SUMBER DAYA MANUSIA PERSPEKTIF AL-QUR'AN
}

Fantika Vera Entrisnasari

Institut Agama Islam Negeri Surakarta

Fantika Febry Puspitasari

Universitas Islam Negeri Maulana Malik Ibrahim

\section{Supriyanto}

Universitas Muhammadiyah Malang

Abstract: Indonesia is predicted to experience a demographic bonus between 2015 and 2035. With the abundance of productive human resources, Islamic education institutions must be ready to manage their human resources with the right strategy to implement. Management of human resources from Al-Quran's perspective is the right choice in an Islamic educational institution, and this management has been implemented in integrated Islamic schools. In this research, a case study will be taken at SDIT Insan Cendekia Boyolali, which is considered useful in implementing human resource management. The implementation carried out by SDIT Insan Cendekia Boyolali starts from four management components: 1) Planning, 2) Organizing, 3) Controlling, 4) Actuating has implemented Al-Qur'an perspective management. Likewise, in the implementation of the principles of human resource management, namely: 1) The principle of monotheism, 2) The principle of justice and welfare, 3) The principle of deliberation, 4) The principles of efficiency, effectiveness, and productivity, 5) The principles of discipline, integrity, and loyalty, 6) The principle of division of authority and responsibility, 7) The Ukhuwah Principle. There are still some deficiencies in the implementation, but educators can already felt the results..

Keywords: Human Resource Development Management; Al Qur'an and Hadith.

Abstrak: Indonesia diprediksikan mengalami bonus demografi antara tahun 2015 sampai 2035. Dengan melimpahnya sumber daya manusia yang produktif, lembaga pendidikan islam harus siap memanajemen sumber daya manusianya dengan strategi yang tepat untuk diimplementasikan. Manajemen sumber daya manusi perspektif al-qur'an merupakan pilihan tepat dalam suatu lembaga pendidikan islam, dan manajemen ini telah diimplementasikan pada sekolahsekolah islam terpadu. Pada penelitian ini akan diambil studi kasus pada SDIT Insan Cendekia Boyolali yang dianggap baik dalam implementasi manajemen sumber daya manusianya. Implementasi yang dilakukan oleh SDIT Insan Cendekia Boyolali mulai dari empat komponen manajemen, yaitu: 1) Planning, 2) Organizing, 3) Controlling, 4) Actuating telah mengimplementasikan manajemen perspektif Al-Qur'an. Begitu juga dalam pelaksanaan prinsip-prinsip manajemen sumber daya manusianya, yaitu: 1)Prinsip Tauhid, 2) Prinsip keadilan dan kesejahteraan, 3) Prinsip musyawarah, 4) Prinsip efisiensi, efektivitas, dan produktivitas, 5) Prinsip disiplin, integritas, dan loyalitas, 6) Prinsip pembagian wewenang dan tanggung jawab, 7) Prinsip Ukhuwah. Masih ada beberapa 
kekurangan dalam pelaksnaannya, namun hasilnya sudah dapat dirasakan oleh para pendidik di sekolah tersebut..

Kata Kunci: Manajemen Sumber Daya Manusia; Al Qur'an dan Hadits.

\section{A. PENDAhuluan}

Berdasarkan kalkulasi Badan Pusat Statistika, era bonus demografi yang terjadi di Indonesia berada antara tahun 2015 sampai 2035 (Falikhah, 2017). Hal ini merupakan potensi yang sangat baik untuk dimanfaatkan menuju negara yang semakin berdaya dengan mengoptimalkan setiap kompetensi dan potensi sumber daya manusia itu sendiri. Sedangkan, jika potensi ini tidak dimanfaatkan dengan baik, maka merupakan kerugian tersendiri karena gagal mengelola potensi yang besar ini.

Pendidikan berperan penting untuk mengelola potensi sumber daya manusia. Pendidikan Islam bertugas menjadikan manusia sadar terhadap penghambaannya pada Allah (Alam, 2016). Lembaga pendidikan Islam harus mengambil peran masing-masing, selain mempersiapkan peserta didik untuk memiliki bekal untuk menghadapi tantangan zaman, lembaga pendidikan Islam juga harus mengelola tenaga pendidik dan tenaga kependidikan untuk dapat mencapai tujuan secara optimal. Lembaga pendidikan Islam harus dapat menciptakan iklim prestatif, sehingga setiap individu yang berada dalam lembaga senantiasa berusaha untuk membuat kemajuan dalam pribadi maupun lembaga.

Islam sebagai way of life mengatur semua hal dalam lini kehidupan yang dijadikan sebagai dasar oleh muslim dalam menjalani kehidupannya. Maka hari ini Pendidikan Islam menghadapi tantangan integrasi dalam Pendidikan. Integrasi pendidikan agama dan sains sangat perlu dilakukan untuk mencapai pendidikan yang berkualitas sehingga membentuk produk Sumber Daya Manusia yang beriman dan bertakwa (Pratiwi, 2014). Maka dalam manajemen sumber daya manusia, telah terdapat ayat-ayat dalam al-qur'an dan Hadits yang dapat dipelajari dan dijadikan sebagai pedoman dalam manajemen sumber daya manusia.

Manajemen sumber daya manusia yang diterapkan dalam lembaga pendidikan islam memiliki ciri khas sendiri yang tidak ditemukan pada lembaga pendidikan umum lainnya (Astuti, 2019). Dalam manajemen sumber daya manusia lembaga pendidikan islam menggunakan perspektif al-qur'an dan hadits dalam prinsipprinsipnya.Prinsip-prinsip manajemen sumber daya manusia perspektif al-qur'an dan hadits inilah yang senantiasa diyakini akan mengantarkan lembaga beserta individu didalamnya untuk mencapai tujuan yang optimal karena melaksanakan sesuai dengan 


\section{Fantika Vera E., Fantika Febry P., Supriyanto}

petunjuk Tuhan. Prinsip-prinsip manajemen sumber daya manusia perspektif Al-Qur'an di antaranya: 1) Prinsip Tauhid, 2) Prinsip keadilan dan kesejahteraan, 3) Prinsip musyawarah, 4) Prinsip efisiensi, efektivitas, dan produktivitas, 5) Prinsip disiplin, integritas, dan loyalitas, 6) Prinsip pembagian wewenang dan tanggung jawab, 7) Prinsip Ukhuwah (Salam, 2014).

Artikel ini akan membahas tentang prinsip-prinsip manajemen sumber daya manusia perspektif al-qur'an dan hadits serta implementasinya dalam sebuah lembaga pendidikan islam yang tergabung dalam Jaringan Sekolah Islam Terpadu (JSIT), yaitu SDIT Insan Cendekia Boyolali. SDIT Insan Cendekia Boyolali menjadi pilihan untuk studi kasus, karena SDIT Insan Cendekia adalah sekolah yang memiliki keunikan dalam mengimplementasikan prinsip-prinsip manajemen sumber daya manusia dalam pengelolaan lembaganya. Hal ini menjadi penting untuk diteliti agar mengetahui terkait efektivitas implementasi prinsip-prinsip manajemen sumber daya manusia dalam suatu lembaga pendidikan islam.

\section{B. METODE}

Penulisan ini menggunakan data primer dan bersifat kualitatif. Data primer adalah data yang dikumpulkan langsung oleh peneliti dari subjek atau objek penelitian. Sedangkan data kualitatif adalah data yang disajikan dalam bentuk kata-kata (tulisan) yang menjelaskan fenomena dan tidak dapat dihitung. Sumber data didapatkan dari hasil studi kasus dari lembaga pendidikan, SDIT Insan Cendekia Boyolali selama satu periode kepemimpinan yaitu Tahun Ajaran 2016/2017 sampai 2019/2020. Metode pengumpulan data yang digunakan penulis adalah observasi partisipatoris, wawancara dan dokumentasi. Observasi partisipatoris adalah observasi yang dilakukan peneliti dengan mengamati dan berpartisipasi langsung dengan kehidupan informan yang sedang diteliti. Metode analisis data yang digunakan adalah dengan mengumpulkan dan mereduksi data.

\section{IMPLEMENTASI MANAJEMEN PERSPEKTIF AL-QUR'AN}

Sekolah Islam Terpadu adalah Sekolah yang tergabung dalam Jaringan Sekolah Islam Terpadu (JSIT), meskipun tidak semua sekolah yang berlabel Islam Terpadu tergabung dalam JSIT. Dalam pelaksanaannya Sekolah Islam Terpadu sudah memiliki acuan atau pedoman pelaksanaan maupun standar yang ditentukan oleh JSIT Pusat.

Sekolah Islam Terpadu (SIT) pada hakikatnya adalah sekolah yang mengimplementasikan konsep pendidikan Islam berlandaskan al-quran dan as sunnah serta dilandasi Undang-Undang Sistem Pendidikan Nasional. Konsep operasional SIT 
merupakan akumulasi dari proses pembudayaan, pewarisan dan pengembangan ajaran agama islam, budaya dan peradaban islam dari generasi ke generasi. Istilah "Terpadu" dalam SIT dimaksudkan sebagai penguat (taukid) dari islam itu sendiri. Maksudnya adalah islam yang utuh, menyeluruh, integral, bukan parsial, syumuliah bukan juz'iyah. Hal ini menjadi semangat utama dalam gerak dakwah di bidang pendidikan ini sebagai “perlawanan” terhadap pemahaman sekuler, dikotomi, dan juz 'iyah (Muhab dkk, 2017).

SDIT Insan Cendekia Boyolali sebagai sekolah islam terpadu yang mengimplementasikan pendidikan islam berdasarkan al-qur'an dan hadits sudah sewajarnya juga mengelola lembaganya dengan perspektif al-qur'an dan hadits pula. Terutama dalam pelaksanaan empat komponen penting dalam manajemen, yaitu planning (perencanaan), organizing (pengorganisasian), actuating (pelaksanaan), dan controlling (pengendalian /evaluasi) (dkk, 2017).

\section{Planning (Perencanaan)}

Perencanaan merupakan suatu hal yang dianjurkan dalam QS. Al-Hasyr (59):

18: “Wahai orang-orang yang beriman, bertakwalah kepada Allah dan hendaklah setiap diri memperhatikan apa yang telah diperbuatnya untuk hari esok (akhirat), dan bertakwalah kepada Allah. Sungguh, Allah Maha Teliti terhadap apa yang kamu kerjakan" (QS. Al-Hasyr (59):18).

Ayat di atas menjelaskan bahwa suatu perencanaan dalam hal manajemen hendaknya menyesuaikan kebutuhan, kondisi, dan pada masa yang telah lalu, hari ini dan hari esok. Untuk memperoleh kesuksesan dalam hal perencanaan, maka diperlukan sebuah ketelitian. Perencanaan menjadi sesuatu yang harus dilaksanakan dalam sebuah lembaga demi mencapai tujuan dan berjalan memilih jalan yang efektif dan efisien. Untuk itu SDIT Insan Cendekia menerapkan perencanaan setiap tahun, setiap bulan dan setiap pekan. Perencanaan setiap tahun dilaksanakan pada agenda rapat program kerja, dalam notulensi rapat yang ada agenda tersebut dilaksanakan menjadi empat tahap, yaitu rapat LPJ untuk mengevaluasi program selama satu tahun, rapat program kerja untuk merencanakan program yang akan dilaksanakan selama setahun, rapat RKAS bersama Yayasan Harapan Insan Boyolali (YAHIB) untuk merencanakan anggaran yang akan digunakan selama satu tahun dan terakhir ditutup dengan rapat RKAS bersama komite untuk merencanakan dana yang dianggarkan dari wali murid selama satu tahun.

Perencanaan tidak hanya cukup dalam satu tahun tersebut, namun perencanaan ini akan kembali dipersiapkan tiap bulannya untuk dikomunikasikan 


\section{Fantika Vera E., Fantika Febry P., Supriyanto}

kepada seluruh asatidz (dewan guru) agar semua dapat mengetahui dan satu pemikiran dalam program yang akan dilaksanakan selama sebulan. Perencanaan bulanan itu akan didetailkan lagi terutama dalam hal teknis dalam rapat pekanan oleh tim manajemen yang terdiri dari Kepala Sekolah, Wakil Kepala Sekolah dan Kepala Urusan yang akan melaporkan program yang akan dilaksanakan dan merencanakan program yang akan dilaksanakan sepekan kedepan dengan melaporkan juga rencana teknis yang akan dilaksanakan sesuai dengan hasil koordinasi dengan masing-masing staff.

Perencanaan ada pembagiannya juga, yaitu perencanaan konsep dan perencanaan teknis. Tim manajemen bertugas untuk mematangkan konsep program yang akan dilaksanakan sampai membentuk panitia jika dibutuhkan, agar jika pada satu bulan terdapat beberapa agenda kepanitiaan yang dibuat bisa di efisienkan dengan membagi menjadi beberapa kepanitiaan yang diperlukan. Sedangkan perencaaan teknis dimatangkan oleh kepanitiaan yang panitia intinya adalah dari staff urusan terkait, sedangkan kepala urusan dan wakil kepala sekolah dijadikan sebagai steering comitee.

2. Organizing (Pengorganisasian)

Kompetensi masing-masing asatidz SDIT Insan Cendekia Boyolali menjadi acuan dalam pengorganisasian. Selain kompetensi loyalitas juga menjadi hal yang penting digunakan sebagai pertimbangan dalam pelimpahan wewenang.

Proses staffing dilaksanakan di awal tahun pelajaran sebelum dilaksanakannya rapat program kerja. Penempatan tim manajemen, staff, job description dan lain-lain ditentukan dari hasil rapat tim manajemen tahun ajaran sebelumnya. Hal ini ditentukan sampai ada mufakat dengan mempertimbangkan segala aspek.

SDIT Insan Cendekia Boyolali memiliki struktur organisasi yang unik, yang jarang digunakan oleh sekolah dasar, yaitu struktur organisasi yang terdiri dari Kepala Sekolah, Wakil Kepala Sekolah, Kaur Kurikulum, Kaur Kesiswaan, Kaur BPI dan Al-Qur'an, Kaur Sarpras dan Kaur Humas. Masing-masing kepala urusan memiliki staff yang membantu dalam pelaksanaan program kerja. Kepala Sekolah bertugas untuk mengkoordinir waka dan para kaur untuk dapat mengoordinir staff dibawahnya dengan optimal. Kepala Sekolah, Badrus Zaman, menyampaikan bahwa superman atau super woman yang bekerja sendiri di lembaga ini tidak diharapkan, karena yang diharapkan adalah adanya super team yang bekerjasama untuk mewujudkan semua program yang direncanakan. 
Pengorganisasian di SDIT Insan Cendekia Boyolali menerapkan konsep satu komando. Komando konsep biasanya diberikan dari hasil rapat tim manajemen disosialisasikan pada seluruh asatidz untuk mendapatkan masukan dan tanggapan. Ketika semua telah disosialisasikan dan disepakati, maka pelimpahan wewenang dari tim manajemen kepada panitia atau wali kelas sebagai eksekutor lapangannya.

Satu komando dalam pengorganisasian ini sangat penting sesuai dengan firman Allah dalam Q.S. Al-Zumar: 29 yang artinya “Allah membuat perumpamaan (yaitu) seorang laki-laki (budak) yang dimiliki oleh beberapa orang yang berserikat yang dalam perselisihan dan seorang budak yang menjadi penuh dari seorang lakilaki (saja). Adakah kedua budak itu sama halnya? Segala puji bagi Allah, tetapi kebanyakan mereka tidak mengetahui”. Ayat ini mengisyaratkan akan adanya kebingungan jika atasan memberikan instruksi yang berbeda-beda.

3. Actuating (Pelaksanaan)

Istilah actuating dalam konsep manajemen dapat dikelompokkan dalam fungsi yang sama dengan directing, commanding, leading dan coordinating (Hartani, 2011). Directing (Pengarahan) dari seorang pemimpin menjadi suatu hal yang penting dalam manajemen. Seorang Kepala Sekolah harus dapat memberikan arahan yang jelas kepada Tenaga pendidik dan kependidikan di sekolah. Selain arahan, Kepala Sekolah sebagai pemimpin juga harus dapat memberikan perintah, bimbingan, teladan yang jelas, sehingga pelaksanaan setiap program dan job description bisa dipahami dan dilakasanakan dengan baik oleh tenaga pendidik dan kependidikan. Sesuai dengan Q.S. An-Nahl: 125 sebagai berikut: "Serulah (manusia) kepada jalan Tuhanmu dengan hikmah dan pelajaran yang baik dan bantahlah mereka dengan cara yang baik. Sesungguhnya Tuhanmu Dialah yang lebih mengetahui tentang siapa yang tersesat dari jalan-Nya dan Dialah yang lebih mengetahui orang-orang yang mendapat petunjuk." Dalam ayat ini menunjukkan bahwa sangatlah penting seorang pemimpin atau Kepala Sekolah dalam hal ini untuk memberikan arahan/seruan, motivasi dan menegur dengan cara yang baik.

SDIT Insan Cendekia Boyolali rutin melaksanakan BEDA (Briefing dan Do'a) untuk koordinasi harian, mengingatkan tentang visi-misi, memastikan setiap asatidz mempersiapkan pembelajaran sebaik mungkin, memberikan motivasi dan menginternalisasi school culture kepada asatidz. School culture ini dibuat agar semua asatidz dapat bekerja optimal sesuai dengan yang diinginkan dan mengharapkan keberkahan dari Allah Ta'ala, serta menjadikannya sebagai arahan 


\section{Fantika Vera E., Fantika Febry P., Supriyanto}

dalam bekerja kepad semua asatidz. School culture yang dimaksud adalah ISI KAIN SUTRA, merupakan singkatan dari Iman Sejati, Istiqomah, Kerjasama, Inovatif, Sungguh-sungguh dan Terampil. Kepala Sekolah terinspirasi hal ini dari Q.S. Ali'Imran: 102-110.

Maksud dari masing-masing singkatan ISI KAIN SUTRA, yaitu: 1) Iman sejati, diharapkan asatidz memiliki iman yang kuat agar tidak hanya trasnfer ilmu pada siswa, namun juga transfer ruhiyah, selain itu iman sejati ini juga berkaitan erat dengan keikhlasan yang harus senantiasa ditanamkan, agar tidak mudah mengeluh atas segala kendala karena yang diharapkan adalah ridha Allah, seperti dalam firman Allah Q.S. Ali-'Imran: 102. 2) Istiqomah, diharapkan asatidz melaksanakan tugas dengan istiqomah sampai akhir hayat dan berpegang teguh pada tali Allah, seperti firman Allah dalam Q.S. Ali-'Imran: 103. 3) Kerjasama, diharapkan asatidz tidak tercerai-berai dalam melaksanakan tugas, namun dapat bekerjasama dan berkolaborasi dalam menyelesaikan setiap amanah yang diberikan padanya. Seperti firman Allah Q.S. Ali-'Imran: 103. 4) Inovatif, diharapkan Asatidz dapat berinovasi dalam melaskanakan tugasnya, terutama dalam mendidik siswa, asatidz dituntut untuk memberikan inovasi dalam pembelajaran yang fokus pada pembentukan karakter siswa yang baik. 5) Sungguh-sungguh, diharapkan asatidz melaksanakan tugasnya dengan penuh kesadaran bahwa tugasnya sebagai pendidik suatu pekerjaan yang remeh, sehingga butuh kesungguhan dan totalitas yang perlu didedikasikan dalam tugas ini. 6) Terampil, diharapkan asatidz sekolah dasar yang biasa dijadikan siswa sebagai contoh dituntut untuk memiliki banyak keterampilan, terutama juga keterampilan dan mengelola pribadi terlebih dahulu untuk menjadi teladan bagi siswa.

\section{4, Controlling (Pengawasan/Pengendalian/Evaluasi)}

Suatu perencanaan belum tentu akan sesuai dengan yang terdapat di lapangan. Sering muncul suatu keadaan yang disebabkan dari faktor internal maupun eksternal dalam diri asatidz yang menyebabkan pelaksanaan program terjadi kesalahan maupun tidak maksimal dalam pelaksanaannya. Sehingga controlling menjadi penting untuk dilaksanakan oleh seorang pemimpin untuk memastikan segala perencanaan dapat terlaksana dengan baik. Controlling merupakan suatu proses untuk mengukur dan menilai pelaksanaan tugas apakah telah selesai sesuai perencanaan. Jika dalam proses tersebut terjadi penyimpangan/ ketidaksesuaian, maka harus segera dikendalikan (Suti, 2011). 
SDIT Insan Cendekia Boyolali memiliki delapan standar mutu dari diknas dan 3 standart mutu dari JSIT yang harus dipenuhi. Untuk memastikan pelaksanaannya, Kepala Sekolah SDIT Insan Cendekia Boyolali membuat program WAGE (Wajib Asyik Gembira Enjoy) untuk membagi hari tiap selapan untuk fokus supervisi 11 standar mutu dari diknas maupun JSIT tersebut. Pembagian hari sebagai berikut: 1) Senin, dibuat kepanjangan semua niat dan yakin, untuk memenuhi standar isi dan kerjasama, 2) Selasa, dibuat kepanjangan semangat belajar siswa, untuk memenuhi standar proses dan sarpras, 3) Rabu, dibuat kepanjangan rajin dan bersungguh-sungguh, untuk memenuhi standar pengelolaan dan pembiayaan, 4) Kamis, dibuat kepanjangan kampus islami, untuk memenuhi standar PAI dan tenaga kependidikan, 5) Jum'at, dibuat kepanjangan juara mendapat hadiah, untuk memenuhi standar SKL dan pembinaan siswa, 6) Sabtu, dibuat kepanjangan semua bersatu, untuk memenuhi standar penilaian. Dengan pembagian hari tersebut tiap selapan (35 hari dalam hitungan jawa) Kepala Sekolah akan supervisi sesuai dengan standar yang sudah dijadwalkan, sedangkan setiap harinya sesuai dengan hari yang dijadwalkan tersebut digunakan Tim Pengembang Sekolah (TPS) untuk fokus memenuhi standar terkait.

Evaluasi di SDIT Insan Cendekia Boyolali dilaksanakan beriringan dengan perencanaan. Sehingga setiap selesai suatu program akan segera di evaluasi dan sekaligus perencanaan program selanjutnya. Evaluasi juga dilaksanakan setiap tahun, setiap bulan dan setiap pekan seperti waktu untuk perencanaan program. Sehingga setiap kali pembahasan ada evaluasi program yang telah terlaksana diikuti program yang akan dilaksanakan.

\section{PRINSIP MANAJEMEN SUMBER DAYA MANUSIA PERSPEKTIF}

\section{AL-QUR'AN}

Lembaga pendidikan islam senantiasa menggunakan perspektif al-qur'an dan hadits dalam ideologi pembentukannya. Namun ideologi ini yang tidak akan berpengaruh jika hanya sebatas administrasi dan tidak pernah digunakan sebagai pedoman manajemen setiap sumber daya yang ada dalam lembaga pendidikan islam tersebut.

Prinsip manajemen sumber daya manusia adalah suatu hal yang sangat penting untuk mencapai tujuan suatu lembaga. Prinsip-prinsip ini juga tidak boleh hanya menjadi suatu dokumen yang tidak pernah diperhatikan, namun pemimpin harus terus menggunakan prinsip ini dalam memanajemen lembaganya. 


\section{Fantika Vera E., Fantika Febry P., Supriyanto}

Pada penjelasan sebelumnya telah dipaparkan tentang implementasi manajemen perspektif al-qur'an pada SDIT Insan Cendekia Boyolali. Dalam paparan empat komponen penting dalam manajemen tersebut sudah tampak beberapa prinsip manajemen sumber daya manusia yang diimplementasikan di SDIT Insan Cendekia Boyolali. Prinsipprinsip manajemen sumber daya manusia yang diimplementasikan di SDIT Insan Cendekia Boyolali, sebagai berikut:

\section{Prinsip Kesatuan Arah dan Kesatuan Komando}

Kepala SDIT Insan Cendekia dalam notulensi rapat tanggal 30 November 2019 pernah menyampaikan arahan tentang sekolah unggul yang diharapkan dapat dicapai oleh lembaga tersebut. Dalam notulensi tersebut disampaikan bahwa Badrus Zaman menganalogikan untuk mencapai sekolah unggul ibarat tenaga pendidik dan kependidikan mengendarai pesawat terbang. Seperti saat naik pesawat. Saat naik pesawat maka penumpang tidak boleh menyalakan hape karena akan mengganggu, dan bisa menimbulkan kecelakaan jika tidak mengikuti instruksi. Sama seperti pesawat, maka untuk menuju tujuan yang dicapai, harus mempunyai kesadaran untuk tidak melakukan hal-hal yang membuat melenceng atau menghalangi tercapainya tujuan, serta mengikuti arahan dari pilot pesawat. Analogi lainnya disampaikan tentang analogi kapal, bahwa kapal itu hanya butuh satu nahkoda yang menentukan arah kapal tersebut, sedangkan jika masing-masing orang dalam kapal menentukan arah, maka mereka tidak bisa mencapai tempat tujuan bersama.

Kedua, analogi yang disampaikan kepala sekolah tersebut, mengindikasikan bahwa manajemen di SDIT Insan Cendekia menjalankan prinsip tauhid dalam manajemen sumber daya manusia, yaitu kesatuan arah dan kesatuan komando. Sekolah adalah organisasi, dan organisasi harus taat asas dan tidak berpeca belah, memegang soliditas, menjaga kekompakan dan kebersamaan. Dalam arahan saat briefing pagi pun kepala sekolah sering mengingatkan untuk mengikuti instruksi sesuai dengan jalurnya. Misal tentang informasi kurikulum, yang menjadi rujukan utama adalah kaur kurikulum, informasi kesiswaan juga dari kaur kesiswaan, dan seterusnya. Yang informasi dari masing-masing kaur tersebut sudah dibahas dalam rapat tim manajemen. Kreativitas dan inovasi memang penting, namun harus menunjang atau menuju visi-misi.

Dalam hal ini SDIT Insan Cendekia Boyolali telah mengimplementasikan

prinsip manajemen sumber daya manusia dalam Q.S. Al-Zumar: 29 yang artinya “Allah membuat perumpamaan (yaitu) seorang laki-laki (budak) yang dimiliki oleh beberapa orang yang berserikat yang dalam perselisihan dan seorang budak yang 
menjadi penuh dari seorang laki-laki (saja). Adakah kedua budak itu sama halnya? Segala puji bagi Allah, tetapi kebanyakan mereka tidak mengetahui”.

2. Prinsip Keadilan dan Kesejahteraan

Prinsip keadilan pada manajemen sumber daya manusia di lembaga pendidikan lebih erat kaitannya dengan numerasi (penggajian), penempatan sesuai bidang keahlian, ataupun masalah hak tenaga kependidikan lain seperti ikut serta dalam organisasi, hak kesehatan dan perlindungan kerja.

SDIT Insan Cendekia Boyolali membuat pembagian hak sesuai jenjang karir asatidz serta lama masa mengabdi. Jenjang karir ini akan dipantau oleh penanggungjawab bidang SDM dari yayasan. Kenaikkan jenjang karir diusulkan oleh Kepala Sekolah berdasarkan penilaian, asatidz sendiri diperbolehkan mengajukan pada Kepala Sekolah jika sudah pantas dan memenuhi syarat.

Jenjang karir menentukan besaran gaji pokok, asatidz yang sudah selesai masa magang akan mendapatkan tunjangan-tunjangan. Tunjangan berupa tunjangan kehadiran, tunjangan tugas dan struktural, tunjangan prestasi.

Masalah penempatan terkadang masih menjadi hal yang rumit, karena guru sekolah dasar harus bisa menguasai semua mata pelajaran, sehingga tendik yang belum menguasai tetap ditempatkan pada penempatan yang paling mendekati sesuai dengan kemampuan, berikutnya dilaksanakan pelatihan-pelatihan untuk meningkatkan kompetensi asatidz, yang dijadwalkan tiap hari sabtu pekan kedua dan keempat.

Hal tersebut merupakan implementasi dari Q.S. An-Nisa': 58 yang artinya "Sungguh, Allah menyuruhmu menyampaikan amanat kepada yang berhak menerimanya, dan apabila kamu menetapkan hukum di antara manusia hendaknya kamu menetapkannya dengan adil. Sungguh, Allah sebaik-baik yang memberi pengajaran kepadamu. Sungguh, Allah Maha Mendengar, Maha Melihat.” Dengan pembagian pekerjaan sebagai kewajiban dan memenuhi hak

3. Prinsip Musyawarah

prinsip musyawarah memegang peranan penting dalam menerapkan prinsip pendidikan karakter (Setiawan, 2014). Seperti yang dilaksanakan di lembaga pendidikan islam lainnya, SDIT Insan Cendekia Boyolali juga melaksanakan musywarah mufakat dalam penentuan hasil suatu permasalahan. Seperti yang telahdipaparkan pada komponen perencanaan, bahwa SDIT Insan Cendekia melaksanakan rapat rutin tahunan, bulanan dan pekanan. 


\section{Fantika Vera E., Fantika Febry P., Supriyanto}

Dalam prinsip musyawarah ini yang seharusnya peserta rapat atau musyawarah menerima hasil yang ditetapkan oleh forum. Namun secara alami tetap saja ada beberapa individu yang terkadang masih belum menerima dengan baik keputusan rapat. Hal ini dianggap menjadi suatu hal yang wajar, dan tidak dipermasalahkan selama tidak mengganggu produktivitas lembaga. Namun perlu dilakukan pendekatan ketika hal ini mengganggu stabilitas dan produktivitas kerja, dengan pendekatan humanis.

Musyawarah juga harus dilaksanakan dengan berlaku lemah lembut, dan menjauhkan diri dari bersikap keras dalam sesuai dengan fiman Allah Q.S. Ali-Imran: 159 yang artinya "Maka berkat rahmat Allah engkau (Muhammad) berlaku lemah lembut terhadap mereka. Sekiranya Engkau bersikap keras dan berhati kasar, tentulah mereka menjauhkan diri dari sekitarmu. Karena itu maafkanlah mereka dan mohonkanlah ampunan untuk mereka, dan bermusyawarahlah dengan mereka dalam urusan itu. Kemudian, apabila engkau telah membulatkan tekad, mka bertakwalah kepada Allah. Sungguh, Allah mencintai orang yang bertawakal. "Namun dilapangan yang sangat dinamis terkadang ada beberapa rapat dengan suasana tegang saat membahas suatu hal. Kepala SDIT Insan Cendekia biasa berperan sebagai penengah dan mengingatkan kembali atas tujuan awal pembahasan tersebut, dengan sebelumnya mengendalikan diri terlebih dahulu.

4. Prinsip Efisiensi, Efektivitas dan Produktivitas

Sesuai dengan paparan dalam komponen manajemen tentang pengorganisasian, bahwa pengaruh iklim suatu organisasi dapat mempengaruhi produktivitas kerja (Kamuli, 2012), di SDIT Insan Cendekia Boyolali membagi sumber daya manusianya dalam struktur organisasi dan disesuaikan dengan kompetensinya. Kepala Sekolah akan menuntut para kaur untuk membagi tugas secara merata dan saling bekerjasama dan dilaporkan perkembangannya setiap pekan.

Berikutnya untuk menjaga prinsip efisien, efektivitas dan produktivitas, maka SDIT Insan Cendekia mengadakan pelatihan-pelatihan rutin yang dilaksanakan setiap hari sabtu pekan kedua dan keempat. Pelatihan ini menjadi suatu hal penting untuk mengarahkan agar asatidz dapat melaksanakan tugasnya dengan prinsip efisien, efektif dan produktif, karena tanpa pemahaman yang baik dan terlatih, seseorang hanya akan terlalu banyak berimprovisasi sehingga tidak dapat melaksanakan tugasnya dengan prinsip tersebut.

Firman Allah dalam Q.S. Al-Isra': 26-27 yang artinya “Dan berikanlah haknya pada kerabat dekat, juga kepada orang miskin dan orang dalam perjalanan, dan 
janganlah kamu, menghambur-hamburkan (hartamu) secara boros. Sesungguhnya orang-orang yang pemboros itu adalah saudara setan dan setan itu sangat ingkar kepada Tuhannya.” Diimplementasikan oleh SDIT Insan Cendekia Boyolali dengan upaya-upaya diatas agar asatidz tidak mengeluarkan energi yang berlebih namun hasil tidka maksimal.

5. Prinsip Disiplin, Integritas dan Loyalitas

Dalam konteks dunia pendidikan, disiplin juga dimaknai sebagai alat untuk menciptakan perilaku dan tata tertib manusia sebagai individu maupun anggota kelompok organisasi (Ramdhani, 2017). SDIT Insan Cendekia Boyolali yang mempunyai tagline Sekolah Presiden (Prestatif - Islami - Disiplin - Enjoy), menjadikan kata disiplin sebagai salah satu karakter utama yang ingin dibangun. Mulai dari penegakkan kedisiplinan pada setiap asatidz dengan memberikan sanksi fisik dan materiil yang harus diterima untuk dihrapan menimbulkan efek jera agar tidak mengulangi ketidakdisiplinan tersebut. Tidak hanya menerapkan punishment tapi juga reward bagi asatidz yang memiliki kinerja baik dan disiplin tinggi berdasar penilaian Kepala Sekolah, reward diberikan pada hari Jum'at yang merupakan singkatan Juara mendapatkan hadiah. Dengan adanya reward, diharapakan hal ini dapat menjadi stimulus agar asatidz tak hanya memiliki disiplin tinggi namun juga motivasi untuk berprestasi, sepeti tagline pertama Sekolah Presiden.

Untuk menguatkan integritas dan loyalitas asatidz SDIT Insan Cendekia Boyolali menguatkan tagline Islami dan Enjoy dalam implementasinya. Kata islami ini diimplementasikan dalam keseharian dengan membentuk lingkungan yang merujuk firman Allah SWT pada Q.S. Al-'Ashr: 1-3, yaitu menciptakan budaya saling menasehati dan kebaikan dan kesabaran. Setiap asatidz mendapatkan pendampingan dari guru senior yang ditunjuk untuk membimbing pemahaman keagamaan dan membersamai dalam pelaksnaan ibadah harian, karena diyakini hal ini akan membangun ketenangan jiwa hingga tercipta suasana yang nyaman atau enjoy dilingkungan sekolah. Selain nyaman yang diimplementasikan dengan membangun ketenangan jiwa dan diharapkan dapat memancing keberkahan jama'ah, nyaman juga diimplementasikan dengan membangun sekolah yang hijau (greenschool). Dengan adanya upaya-upaya tersebut diharapkan tumbuh integritas yang dilandaskan karena mengharap ridha Allah dan loyalitas karena telah merasakan kenyamanan yang tercipta di lingkungan sekolah. 


\section{Fantika Vera E., Fantika Febry P., Supriyanto}

Prinsip yang digunakan oleh SDIT Insan Cendekia Boyolali ini merupakan implementasi dari Q.S. An-Nisa: 59 yang artinya “Wahai orang-orang yang beriman! Taatilah Allah dan taatilah Rasul (Muhammad), dan Ulil Amri (pemegang kekuasaan) diantara kamu. Kemudian jika kamu berbeda pendapat tentang sesuatu, maka kembalikanlah kepada Allah (Al-Qur'an) dan Rasul (sunnah-nya), jika kamu beriman kepada Allah dan harikemudian. Yang demikian itu, lebih utama (bagimu) dan lebih baik akibatnya." Berdasarkan ayat tersebut disiplin dalam perspektif al-qur'an merupakan ketaatan pada Allah, Rasul dan ulil amri (pemegang kekuasaan), jika dilingkungan sekolah maka taat kepada Kepala Sekolah selama tidak mengajak pada kemungkaran.

6. Prinsip Pembagian Wewenang dan Tanggung Jawab

SDIT Insan Cendekia Boyolali membagi wewenang dalam lima kaur yang disebut sebagai tim manajemen untuk menjadikan lembaga semakin produktif karena ada pembagian pekerjaan yang jelas dan fokus. Kepala Sekolah memilih personil dalam tim manajemen adalah dengan mempertimbangkan kompetensi, loyalitas dan yang paling utama yaitu kemampuan personil tersebut dalam memahami tujuan lembaga atau visi-misi. Sehingga diharapkan Kepala Sekolah lebih mudah mengarahkan lembaga untuk mencapai tujuan bersama tim yang siap totalitas mendukung jalannya lembaga untuk menuju tujuan yang ingin dicapai.

Tim manajemen sebagai middle manajer yang diharapkan mampu memaksimalkan kompetensi para staff dalam bentuk tim kerja. Tim manajemen bertanggung jawab dan memiliki wewenang atas bidang masing-masing setelah direncanakan secara kolaboratif dalam tim manajemen itu sendiri. Sehingga sumber daya manusia dapat dioptimalkan, karena setiap bidang memiliki motor penggeraknya, sehingga laju arah lembaga untuk mecapai tujuan bisa maksimal.

Dalam hal ini SDIT Insan Cendekia mengimplementasikan Q.S. Al-An'am: 135 yang artinya “Katakanlah (Muhammad), ”Wahai kaumku! Berbuatlah menurut kedudukanmu, akupun berbuat (demikian). Kelak kamu akan mengetahui, siapa yang akan memperoleh tempat(terbaik) di akhirat (nanti). Sesungguhnya orang-orang yang zalim itu tidak akan beruntung."

7. Prinsip Ukhuwah

Persamaan tujuan yang menjadi ikatan ukhuwah yang dibangun di SDIT Insan Cendekia adalah untuk mendapatkan ridha Allah SWT. Dengan adanya kesamaan tujuan hakiki tersebut asatidz dapat merasakan ukhuwah islamiyyah dan menerapkan proses ukhuwah (Laili, 2016), Sebagai berikut: 1) Ta'aruf, yaitu saling mengenal, 
2)Tafahum, yaitu saling memahami, 3)Ta'awun, yaitu saling membantu dalam melaksanakan kebaikan, 4)Ta'aluf, yaitu bersatunya seorang muslim dengan muslim lainnya. 5)Takaful, yaitu saling membantu.

SDIT Insan Cendekia mengupayakan ukhuwah yang kuat dari asatidz dengan menjadikan wakil kepala sekolah dan kaur humas sebagai penanggung jawabnya. Upaya tersebut dilakukan dengan dua cara. Pertama, dengan mengagendakan program-program untuk mendekatkan silaturahim masing-masing asatidz, seperti program silaturahim keluarga, family gathering, outbound, jengukan ketika ada yang sakit, menikah, melahirkan. Dengan program kultural tersebut diharapkan dapat mendekatkan ikatan hati para asatidz. Kedua, Kepala SDIT Insan Cendekia meyakini bahwa adanya ukhuwah yang kuat itu karena adanya kesamaan frekuensi ruhiyah dari masing-masing asatidz. Sehingga upaya yang dilakukan adalah dengan rutin memberikan tausiyah dan motivasi saat briefing, program One Day One Juz (ODOJ), dan monitoring pelaksanaan amalan harian yang diiringi dengan tausiyah-tausiyah agar asatidz melaksanakan amalan tersebut atas kesadaran pribadi.

Ukhuwah islamiyyah ini sangat penting dibentuk dalam suatu lembaga untuk meningkatkan kepekaan terhadap sesama asatidz, sehingga budaya kerjasama dan saling membantu dengan sukarela dapat terlaksana dalam kesehariannya. Sehingga akan mampu menjadikan lembaga semakin produktif. Ukhuwah islamiyah yang dibentuk pada SDIT Insan Cendekia Boyolali ini merupakan implementasi dari Q.S. Al-Hujurat: 10 dan 13, yang artinya "Sesungguhnya orang-orang mukmin itu bersaudara, karena itu damaikanlah anatara kedua saudaramu (yang berselisih) dan bertakwalah kepada Allah agar kamu mendapat rahmat. Wahai manusia! Sungguh, kami telah menciptakan kamu dari seorang laki-laki dan seorang perempuan, kemudian Kami jadikan kamu berbangsa-bangsa dan bersuku-suku agar kamu saling mengenal.Sungguh, yang paling mulia diantara kamu disisi Allah ialah orang yang paling bertakwa. Sungguh, Allah Maha Mengetahui, Maha Teliti.”

\section{E. KESIMPULAN}

Manajemen sumber daya manusia yang dilaksanakan di SDIT Insan Cendekia Boyolali sebagai Sekolah Islam Terpadu adalah manajemen sumber daya manusia yang berdasar perspektif al-qur'an. Dalam pengimplementasian empat komponen manajemennya pun sesuai dengan dalil dalam al-qur'an dengan melakukan upaya-upaya pelaksanaannya agar optimal. Prinsip-prinsip dalam manajemen sumber daya manusia 


\section{Fantika Vera E., Fantika Febry P., Supriyanto}

juga mengambil perspektif al-qur'an. Prinsip-prinsip yang dilaksnaakan antaralain:1)Prinsip Tauhid, 2) Prinsip keadilan dan kesejahteraan, 3) Prinsip musyawarah, 4) Prinsip efisiensi, efektivitas, dan produktivitas, 5) Prinsip disiplin, integritas, dan loyalitas, 6. Prinsip pembagian wewenang dan tanggung jawab, 7) Prinsip Ukhuwah. Dengan adanya prinsip-prinsip manajemen sumber daya manusia yang sesuai dengan perspektif islam, yang meskipun dalam implementasi lapangannya masih terdapat kekurangan, namun suasana harmonis yang tercipta dilingkungan sekolah sudah dapat dirasakan oleh para asatidz SDIT Insan Cendekia dan tercipta ghirah positif untuk bekerjasama memajukan lembaga.

\section{DAFTAR PUSTAKA}

Alam, Lukis. (2016). Internalisasi Nilai-Nilai Pendidikan Islam Dalam Perguruan Tinggi Umum Melalui Lembaga Dakwah Kampus. Istawa: Jurnal Pendidikan Islam. 1(2), 101-120. Doi: 10.24269/ijpi.v1i2.171

Astuti, Efi Tri. (2019). Prinsip Manajemen Tenaga Kependidikan Perspektif Al-Qur'an. Jurnal Iqra': Kajian Ilmu Pendidikan. 4(1), 128-145. https://doi.org/10.25217/ji.v4i1.465

Falikhah, Nur. (2017). Bonus Demografi Peluang Dan Tantangan Bagi Indonesia. Jurnal Alhadharah: Ilmu Dakwah. 16(32), 1-12. http://dx.doi.org/10.18592/alhadharah.v16i32.1992

Hartani, A. L. (2011). Manajemen Pendidikan (S. Purba, Ed.). (http://digilib.unimed.ac.id/1614/)

Ikhwan, A. (2016). Manajemen Perencanaan Pendidikan Islam (Kajian Tematik AlQur'an dan Hadits). Edukasi: Jurnal Pendidikan Islam, 4(1), 128-155.

Kamuli, S. (2012). Pengaruh Iklim Organisasi terhadap Produktivitas Kerja Pegawai di Sekretariat Daerah Kota Gorontalo. Jurnal Inovasi. 9(1), 1-8.

Laili, Syarifah. (2016). Studi Analisis Ayat-Ayat Ukhuwah dalam Tafsir Al-Mishbah Karya Quraish Shihab. Tesis, Fakultas Ushuluddin. Medan: Universitas Islam Negeri Sumatera Utara.

Muhab, Suko, et al. (2017). Standar Mutu Kekhasan Sekolah Islam Terpadu. Jakarta: JSIT Indonesia.

Pratiwi, Umi. (2014). Integrasi Pendidikan Agama-Sains Berbasis Eksperimental Untuk Membentuk Character Building Mahasiswa. Insania: Jurnal Pemikiran Alternatif Kependidikan. 19(2), 359-384. https://doi.org/10.24090/insania.v19i2.720

Ramdhani, M. A. (2017). Lingkungan Pendidikan dalam Implementasi Pendidikan Karakter. Jurnal Pendidikan UNIGA. 8(1), 28-37. 
Salam, A. (2014). Manajemen Insani Dalam Pendidikan. Yogyakarta: Pustaka Pelajar. Setiawan, A. (2014). Prinsip Pendidikan Karakter dalam Islam: Studi Komparasi Pemikiran Al-Ghazali dan Burhanuddin Al-Zarnuji. Dinamika Ilmu. 14(1), 112. https://doi.org/10.21093/di.v14i1.4

Suti, M. (2011). Strategi peningkatan mutu di era otonomi pendidikan. Jurnal Medtek, $3(2), 1-6$. 